\title{
PROBLEMATIKA PEMBERDAYAAN KOMUNITAS ADAT TERPENCIL (KAT) SUKU SAKAI DI KECAMATAN BATHIN SOLAPAN KABUPATEN BENGKALIS
}

\author{
Abu Bakar \\ Dosen Fakultas Ushuluddin UIN Sultan Syarif Kasim Riau \\ Email : jambuair@gmail.com \\ Abd. Ghofur \\ Dosen Fakultas Ushuluddin UIN Sultan Syarif Kasim Riau \\ Email :ghofur06@yahoo.com
}

\begin{abstract}
Abstrak
Persebaran pemukiman Suku Sakai di Kecamatan Bathin Solapan Kabupaten Bengkalis yaitu di Desa Kesumbo Ampai; Desa Petani (dusun Belading \pm 112 KK) dan Desa Bumbung (dusun $V$ Talang Jenang atau Talang Nagoi $\pm 60 \mathrm{KK}$ ). Mayoritas orang sakai bermukim di Desa Kesumbo Ampai \pm 173 KK yang terdiri dari tiga Dusun yaitu dusun Sebangar Asal; Dusun Patang Butam; dan dusun Tanah Pujung. Suku Sakai mayoritas menempati wilayah Dusun Sebanga Asal di mana di dusun ini pula berdiri rumah adat; di kelilingi hutan adat seluas $\pm 260 \mathrm{Ha}$. Program pemberdayaan bagi suku sakai telah dilakukan oleh pihak pemerintah maupun swasta meliputi beberapa hal yaitu pemberian beasiswa; bidang peternakan; pertanian dan perkebunan; program Alokasi Dana Desa dan program UED-SP. Bila dikelompokekan program itu ada dikategorikan sifatnya produktif dan non produktif. Bantuan sifatnya non-produktif tidak banyak mengalami kendala seperti bantuan langsung dalam bentuk beasiswa; bantuan rumah RLH; bantuan uang untuk karang taruna; posyandu; PKK; surau dan masjid. Problem program pemberdayaan produktif mengalami beberapa kendala karena kurangnya pendampingan dan pelatihan yang sustainable (berkelanjutan). Tulisan ini mencoba mengurai berbagai persoalan kendala dari program pemberdayaan bagi suku Sakai.
\end{abstract}

Keywords : Sakai, Pemberdayaan; dan People Centre.

\section{Pendahuluan}

Pemberdayaan adalah sebuah konsep pembangunan masyarakat yang merangkum dan melibatkan nilai-nilai sosial-budaya masyarakat. Konsep ini mencerminkan paradigma baru pembangunan, yakni bersifat "peoplecentered", participatory, empowering, and sustainable (Friedman, 1998: 54). Konsep pemberdayaan lebih luas dari hanya semata-mata untuk memenuhi kebutuhan dasar atau mekanisme untuk mencegah proses pemiskinan, yang pemikirannya saat ini lebih banyak dikembangkan sebagai upaya mencari konsep-konsep peningkatan kualitas hidup masyarakat. Program 
pemberdayaan masyarakat dikatakan terencana apabila pembangunannya mempertimbangkan aneka akses, partisipasi, kontrol dan manfaaat yang setara dan seimbang diterima oleh semua komponen atau kelompok masyarakat; kaya-miskin, tua-muda, laki-lakiperempuan, berdaya-tak berdaya, difabelnon-difabel, masyarakat biasa, masyarakat adat tertinggal dan sebagainya.( Rinnusu,2014: 6.

Ada sebagian masyarakat yang tinggal di desa terisolasi secara fisik dan kebudayaanya disebabkan oleh beberapa alasan, pertama, masyarakat yang tinggal di desa-desa terpencil itu sendiri yang justru mengisolasi diri dari pengaruh kebudayaan luar seperti Komunitas Adat Terpencil (KAT) yang tersebar di beberapa kabupaten di propinsi Riau, seperti Kabupaten Bengkalis, Meranti, dan Siak. Kedua, keadaan geografis yang sulit dihubungkan dengan desa-desa lain atau kota kecil lain sehingga warganya tidak bisa mengakses berbagai fasilitas yang tersedia. Ketiga, kendati satuan wilayahnya mudah terjangkau tetapi karena masyarakatnya sendiri tidak mau berinteraksi dengan masyarakat luar karena alasan-alasan menjaga adatisitiadat yang asli atau karena alasan lain. Tiga ciri tersebut paling tidak bisa menandai batas-batas pengertian mengenai Komuintas Adat Terpencil (KAT) atau masyarakat terpencil yang dibedakan dengan masyarakat pedesaan yang selama ini dikenal.
Berdasarkan Keppres No. 111/1999 Pasal 2, dijelaskan tentang pembinaan kesejahteraan sosial Komunitas Adat Terpencil (KAT) diamanatkan bahwa Pembinaan kesejahteraan sosial komunitas adat terpencil bertujuan untuk memberdayakan komunitas adat terpencil dalam segala aspek kehidupan dan penghidupan agar mereka dapat hidup secara wajar baik jasmani, rohani, dan sosial sehingga dapat berperan aktif dalam pembangunan, yang pelaksanaannya dilakukan dengan memperhatikan dan tidak boleh mengabaikan adat istiadat, dan nilai-nilai sosial-budaya setempat.

Keterasingan sebuah masyarakat dengan beberapa alasan di atas, sebenarnya telah diupayakan pemberdayaan oleh pemerintah maupun kelembagaan lain. Hal ini mengingat perubahan sebuah masyarakat ke arah yang lebih maju dari berbagai sisi baik nilai, norma, budaya, pembangunan fisik maupun non fisik adalah sebuah keniscayaan.

Penelitian tentang Komunitas Adat Terpencil (KAT) khususnya suku Sakai di Kecamatan Batin Solapan kabupaten Bengkalis telah banyak dilakukan dengan berbagai pendekatan, mengingat suku Sakai memiliki karakteristik unik dan belum terjadi perubahan yang lebih baik sisi ekonomi, sosial, budaya dan pendidikannya. Penelitian tentang identifikasi 
problematika pemberdayaan komunitas adat terpencil (KAT) khususnya suku Sakai di Kecamatan Bathin Solapan Kabupaten Bengkalis masih belum dilakukan.

$$
\text { Pentingnya identifikasi }
$$
problematika program pemberdayaan masyarakat khususnya Komunitas Adat Terpencil suku Sakai pada dasarnya untuk menilai sejauh mana efektifitas dan progres dari suatu program setelah beberapa waktu dilaksanakan di suatu desa atau wilayah. Berdasarkan pengamatan pendahuluan (preliminary research) bahwa telah terdapat programprogram pemberdayaan yang dilakukan pemerintah terhadap Suku Sakai di Duri Kabupaten Bengkalis dan kelembagaan lain, misalnya sejak tahun 1963 ada upaya pemerintah mendirikan Pos PMT (pemukiman Masyarakat Terasing) oleh Kantor Inspeksi Sosial Riau dari tahun 1964-1970. Saat itu pembinaan dan pemberdayaan pemerintah terhadap suku Sakai sebatas aspek fisik dan kurang memperhatikan aspek sosial budaya hingga tidak berjalan dengan baik.

Kemudian pada tahun 1976 muncul program pengganti dengan nama PKMT (Pembinaan Kesejahteraan Masayarakat Terasing) diantara kelompok yang dibina adalah PKMT buluh Kasab (1977); PKMT Buluh Kasab (1979); PKMT Sialang Rimbun (1979); PKMT Kandis (1980), namun hasil program pemberdayaan ini banyak menimbulkan hal-hal yang tidak menguntungkan bagi suku Sakai.(Husni Thamrin, 2003, 7).

Pada tahun 1994, Suparlan melakukan penelitian bahwa program PKMT di Sialang Rimbun yang semula berjumlah 75 rumah warga Sakai, ternyata yang dihuni suku Sakai tinggal 18 rumah, dengan keadaan bentuk tiang yang sudah roboh dan sebagian besar mereka kembali ke pemukiman Sakai asal.( Parsudi Suparlan, 1998: 39).

Berdasarkan pengamatan beberapa permasalahan di atas, menarik untuk dilakukan penelitian berkenaan dengan identifikasi problematika program pemberdayaan masyarakat Komunitas Adat Terpencil (KAT) suku Sakai di Kecamatan Bathin Solapan Kabupaten Bengkalis. Rumusan masalah penelitian ini adalah

Pertama, Apa saja Program pemberdayaan masyarakat Komunitas Adat Terpencil (KAT) suku Sakai di Kecamatan Bathin Solpan? Kedua, Bagaimana efektifitas Program pemberdayaan masayarakat Komunitas Adat Terpencil (KAT) suku Sakai di Kecamatan Bathin Solapan? Dan Ketiga, Apa saja persoalan-persoalan yang dihadapi Komunitas Adat Terpencil (KAT) suku Sakai dalam proses perubahan sosial di Kecamatan Bathin Solapan Kabupaten Bengkalis?

\section{Kerangka Teori}

Ada beberapa konsep yang bisa dipakai untuk menjawab permasalahan 
penelitian di atas yaitu :Pemberdayaan Komunitas Adat Terpencil (KAT) suku Sakai, perlu pendekatan dan pemberdayaan khusus sebagaimana caracara belajar orang asli (indegenous learning sistem).

Dalam penelitian Francisco terdapat tiga aspek pendekatan pemberdayaan komunitas Adat yaitu life cycle complex, social control mechanism dan ritual yang diterapkan dalam sistem kepercayaan orang-orang asli. Anak-anak mematuhi pantang-larang yang telah dibuat, mengikuti upacara ritual, dan melakukan tindak-tanduk yang dapat diterima dalam masyarakatnya melalui proses sosialisasi dari keluarga. Mereka menerima dan mempelajari nilai-nilai dari masyarakat yang dibutuhkana sebagai acuan untuk menempuh kehidupan. (Mohammad Zein, 2006: 127).

Pemberdayaan masyarakat (community empowerment) memiliki makna meningkatkan kemampuan atau meningkatkan kemandirian masyarakat. Pemberdayaan masyarakat bukan hanya meliputi penguatan individu-individu dalam masyarakat tetapi mencakup pranata-pranata sosial lainnya.

Ciri-ciri masyarakat yang berdaya menurut Soemodiningrat antara lain memiliki kemandirian khususnya dalam penyediaan kebutuhan hidup mereka serta tanpa memerlukan bantuan dari pihak lain; adanya kebebasan dalam diri untuk menentukan pilihan sendiri; tidak bergantung kepada pihak luar dalam penyediaan sumber daya yang dibutuhkan serta mau menciptakan alternatif serta tatanan ekologis, sosial, budaya, dan eknomi berkelanjutan di tingkat lokal masyarakat; munculnya partisipasi aktif dari masyarakat pada semua program pemberdayaan khususnya dalam perencanaan dan pelaksanaannya. (Mohammad Zein, 2006: 127).

Program pemberdayaan pada dasarnya bagian dari konsep pembangunan masyarakat. Menurut UU No. 25 Tahun 2004, pembangunan masyarakat memerlukan perencanaan, karena membutuhkan proses untuk menentukan tindakan masa depan yang tepat, melalui urutan pilihan dengan memperhitungkan sumber daya yang tersedia. Sistem perencanaan pembangunan nasional adalah satu kesatuan tata cara perencanaan pembangunan untuk menghasilkan rencana pembangunan dalam jangka panjang, jangka menengah dan tahunan yang dilaksanakan oleh unsur penyelenggara negara dan masyarakat di tingkat pusat dan daerah (Rinnusu, 2014 :8).

Menurut Ginanjar Kartasasmita memberdayakan masyarakat adalah upaya untuk meningkatkan harkat dan martabat kelompok masyarakat yang tidak mampu untuk melepaskan diri dari perangkap kemiskinan dan keterbelakangan. Dengan demikian 
memberdayakan masyarakat adalah memampukan dan memandirikan masyarakat agar dapat bertahan hidup, dan mampu mengembangkan diri untuk mencapai kemajuan. (Ginnanjar Kartasasmita, 2000 : 43).

Upaya penting dan mendasar dalam rangka pemberdayaan masyarakat adalah peningkatan taraf pendidikan, kesehatan, serta akses terhadap sumbersumber kemajuan ekonomi, seperti: modal, teknologi, informasi dan pasar dan sarana prasaran jalan, pasar, serta sekolah.

Kegagalan dan keberhasilan pemberdayaan masyarakat (community empowerment) sangat ditentukan oleh kemampuan semua pihak yang terlibat dalam proses pengembangan masyarakat untuk memahami realitas masyarakat; lingkungan; sistem kepercayaan; sistem nilai sosial-budaya masyarakat tentang arti perubahan. Pemberdayaan masyarakat berupaya meningkatkan pendapatan masyarakat, diperlukan adanya berbagai akses yang mendukung diantaranya; sumberdaya fisik; pembiayaan; akses terhadap teknologi tepat guna; informasi dan pasar. Demikian pula akses untuk mendapatkan pendidikan, pelatihan, dan bimbingan agar masyarakat dapat diberdayakan hingga mampu meningkatkan kesejahteraannya.

\section{Desain Penelitian}

Penelitian ini menggunakan metode penelitian kualitatif. Menurut
Bodgan dan Taylor, metode kualitatif merupakan prosedur penelitian yang menghasilkan data deskreptif berupa kata-kata tertulis atau lisan dari orang dan prilaku yang diamati (Moelong Lexi, 2000: 3). Penelitian ini juga menggunakan pendekatan penelitian kualitatif dengan tradisi penelitian studi Kasus. Studi kasus merupakan penelitian empiris yang menyelidiki dan menguraikan fenomena terkini dalam konteks kehidupan nyata. dengan menggunakan berbagai sumber yaitu observasi, wawancara, dan dokumen.

Penelitian ini menggunakan langkah-langkah $\quad 14 \quad$ karakteristik pendekatan kualitatif menurut Lincoln dan Guba (Chaidir Al-wasilah, 2002 : 104-107), berikut ini :1. Latar ilmiah (natural setting). 2. Manusia sebagai instrumen (buman instrument). 3. Penggunaan pengetahuan yang tidak eksplisit. 4. Metode-metode kualitatif. 5. Sampel purposif (purposive sampling). 6. Analisis data induktif. 7. Teori berdasarkan data di lapangan (grounded theory). 8. Desain penelitian mencuat secara alamiah (emergent design). 9. Hasil penelitian berdasarkan negosiasi. 10 . Cara pelaporan studi kasus (case study reporting mode). 11. Interpretasi kontekstual 12. Aplikasi temuan tentatif.13. Batasan ditentukan focus.14. Keterpercayaan dengan kriteria khusus.

Penelitian dimulai dengan menggali informasi secara mendalam (lingkungan fisik, lingkungan sosial, 
budaya, nilai-nilai yang dianut suku Sakai). Karena data ini untuk menggambarkan keberadaan suku Sakai bagaimana mereka hidup dan mempertahankannya. Proses pengumpulan data dilakukan beberapa tahapan berikut. Pertama, Melakukan identifikasi ulang daerah hunian suku Sakai yang ada di wilayah itu. Kedua, menyusun items (variable) yang bisa segera dicari dari dokumen pemerintah, dan pelacakan langsung ke lapangan.

\section{Sasaran dan Sumber Data}

Sasaran penelitian ini adalah Komunitas Adat Terpencil (KAT) Suku Sakai di Kecamatan Bathin Solapan yang tersebar di beberapa desa. Fokus penelitiannya adalah untuk menelaah secara mendalam problematika pemberdayaan Komunias Adat Terpencil (KAT) suku Sakai yang dilakukan pemerintah dan lembaga lain.

Sedangkan sumber data penelitian ini adalah aparat pemerintah Kabupaten dan Kecamatan seperti dinas sosial, dan aparat kecamatan, tokoh Adat sakai, aparat desa dan tokoh agam yang bisa memberikan jawaban mengenai persoalan penelitian. Teknik pengumpulan data diperoleh melalui observasi dan wawancara mendalam dari informan, di mana informan dipilih secara purposif atau dengan menggunakan model snow ball. Informan dalam penelitian ini nantinya terdiri dari informan pangkal dan informan kunci (key informan). Menurut Koentjaraningrat informan pokok adalah orang yang dipandang mampu memberikan informasi secara umum dan mampu menunjuk orang lain sebagai informan pangkal yang dapat memberikan informasi yang lebih mendalam.( Kontjoroningrat, 1992: 130).

\section{Teknik pengumpulan data}

Teknik pengumpulan data dalam penelitian ini adalah peneliti sebagai instrumen. Peran peneliti menentukan dalam setiap proses penjaringan data. Ciri-ciri umum manusia sebagai instrumen mencakup segi responsiv, dapat menyesuaikan diri, menekankan keutuhan, mendasarkan diri atas pengetahuan, memproses data secepatnya(Moelong Lexi, 2000: 32). Data dalam penelitian ini dikumpulkan berdasarkan pengelompokan data primer dan data sekunder. Teknik pengumpulan datanya adalah wawancara mendalam, observasi atau pengamatan dan penggunaan dokumen.

\section{Teknik Analisis Data}

Untuk menata secara sistematis catatan hasil observasi, wawancara dan dokumentasi, analisis data menggunakan tahapan model Mathew dan Huberman (Mathew Miles \& Hubermen Micahel, 1992: 76) :

a. Kategorisasi dan mereduksi, yaitu melakukan pengumpulan semua informasi penting terkait dengan masalah penelitian ini. 
b. Data yang telah dikelompokkan lalu disusun dalam bentuk narasi-narasi, sehingga data berbentuk rangkaian informasi yang bermakna sesuai.

c. Melakukan interpretasi data, yaitu dengan menginterpretasi apa yang telah diberikan informan terhadap masalah yang diteliti.

d. Pengambilan kesimpulan berdasarkan susunan narasi yang telah disusun pada tahap ketiga, hingga dapat memberi jawaban atas masalah penelitian.

e. Melakukan verifikasi hasil analisis data dengan informan, yang didasaarkan pada simpulan tahap keempat, untuk menghindari kesalahan interpretasi dari hasil wawancara dengan sejumlah informan.

\section{Hasil Penelitian dan analisis}

Kecamatan Mandau berdasarkan data statistik BPS tahun 2017 luas wilayahnya $937,47 \mathrm{Km}^{2}$, terbagi ke dalam 24 desa/kelurahan. Pada bulan Februari tahun 2017 Kecamatan Mandau dimekarkan menjadi dua kecamatan yaitu

Pertama, Kecamatan Mandau meliputi $11 \mathrm{desa} /$ kelurahan yang status hukumnya sudah menjadi desa/kelurahan defenitif. Kedua, Kecamatan baru, yaitu Bathin Solapan yang membawahi 13 desa/kelurahan. Kecamatan Bathin Solapan, membawahi 13 desa yaitu : 1. Desa Buluh Manis; 2. Desa Petani; 3. Desa Tambusai Batang Doi; 4. Desa Simpang Padang; 5. Desa Pematang Obo; 6. Desa Air Kulim; 7. Desa Sebangar ; 8. Desa Boncah Mahang; 9. Desa Bathin Sobanga ;10. Desa Pamesi; 11. Desa Balai Makam ;12. Desa Kesumbo Ampai ; dan 13. Desa Bumbung.

Tabel. 1

Jumlah penduduk Kecamatan Bathin Solapan

\begin{tabular}{|c|l|r|r|r|r|}
\hline NO & \multicolumn{1}{|c|}{ Kelurahan/Desa } & Laki-Laki & Perempuan & \multicolumn{1}{c|}{ Jumlah } & \multicolumn{1}{c|}{ KK } \\
\hline 1 & Balai Makam & 5.520 & 5.042 & 10.562 & 2.688 \\
\hline 2 & Petani* & 3.879 & 3.582 & 7.461 & 2.082 \\
\hline 3 & Sebangar & 5.245 & 4.816 & 10.061 & 2.338 \\
\hline 4 & Bumbung* & 2.090 & 1.924 & 4.014 & 1.090 \\
\hline 5 & Kesumbo Ampai* & 3.403 & 3.094 & 6.497 & 1.658 \\
\hline 6 & Tambusai Batang Doi & 6.501 & 6.003 & 12.504 & 3.218 \\
\hline 7 & Simpang Padang & 7.052 & 6.590 & 13.642 & 3.419 \\
\hline 8 & Pematang Obo & 3.251 & 2.916 & 6.167 & 1.525 \\
\hline 9 & Air Kulim & 3.223 & 3.015 & 6.238 & 1.655 \\
\hline 10 & Buluh Manis & 2.236 & 2.119 & 4.355 & 1.149 \\
\hline 11 & Boncah Mahang & 5.499 & 5.126 & 10.625 & 3.167 \\
\hline 12 & Parmesi & 1.306 & 1.159 & 2.465 & 641 \\
\hline 13 & Bathin Sobanga & 1.407 & 1.304 & 2.711 & 748 \\
\hline & & $\mathbf{5 0 . 6 1 2}$ & $\mathbf{4 5 . 3 8 6}$ & $\mathbf{9 7 . 3 0 2}$ & $\mathbf{2 5 . 3 7 8}$ \\
\hline
\end{tabular}

Data Monografi Kecamatan 2016 dan hasil Observasi lapangan! 
Berdasarkan peta yang dibuat oleh Moszkowski, seorang antropolog Jerman yang melakukan penelitian tentang Sakai tahun 1911, wilayah Suku Sakai meliputi Minas, Belutu, Tingaran, Sinangan, Semunai, Panaso dan Borumban. Akan tetapi wilayah yang masih memiliki tanah ulayat dan benar-benar alami terlihat eksistensinya sebagai Desa Adat; hukum adat; struktur sistem sosial Bathin serta terjaganya hutan adat adalah di Kecamatan Bathin Solapan Desa Kesumbo Ampai(Ahmad Arif, 2007:14.)

\section{Keadaan Pendidikan}

Perkembangan pendidikan di Kecamatan Mandau dan Kecamatan Pemekaran yaitu Bathin Solapan terus berbenah dan terus mendapat perhatian baik pemerintah maupun swasta. Jumlah sarana pendidikan di Kecamatan Mandau dan Bathin Solapan relatif banyak dan cukup merata di seluruh desa/kelurahan. Berdasarkan data BPS Kecamatan tahun 2016, bahwa sarana pendidikan berjumlah 223 unit, dengan perincian 67 unit Taman Kanak-Kanak, 103 unit Sekolah Dasar, 29 unit Sekolah Menengah Pertama, 17 unit Sekolah Menengah Atas, dan 7 unit Sekolah Menengah Kejuruan. Hampir seluruh desa/kelurahan memiliki Sekolah Dasar sebagai sarana pendidikan dasar untuk masyarakat. Tingkat rasio murid-guru cenderung bervariasi pada tiap jenjang pendidikan. Secara rata-rata, rasio muridguru di Kecamatan Mandau sebesar 1516 murid per guru. Rasio murid-guru tertinggi berada pada jenjang Sekolah Dasar yang mencapai 30 murid untuk tiap guru.

\section{Suku Sakai dan persebarannya}

Persebaran pemukiman Suku Sakai di Kecamatan Mandau setelah pemekaran 5 Juni 2017, mereka saat ini berada di beberapa desa di Kecamatan Bathin Solapan yaitu di Desa Kesumbo Ampai; Desa Petani (pemukiman sakai di dusun Belading $\pm 112 \mathrm{KK}$ )(Wawancara, Jamal: -05-09-2017). dan Desa Bumbung ( pemukiman sakai di dusun $\mathrm{V}$ Talang Jenang atau Talang Nagoi $\pm 60 \mathrm{KK}$ ). Mayoritas orang sakai bermukim di Desa Kesumbo Ampai $\pm 173 \mathrm{KK}$ (Wawancara: Anita, 06-08-2017) yang terdiri dari tiga Dusun yaitu dusun Sebangar Asal; Dusun Patang Butam; dan dusun Tanah Pujung. Suku Sakai mayoritas menempati wilayah Dusun Sebanga Asal di mana di dusun ini pula berdiri rumah adat; di kelilingi hutan adat yang masih alami seluas \pm 260 Ha. (Wawancara: Swardino, 04-09-2017) Peran Bathin yang dipimpin oleh Babak M. Yatim di desa Kesumbo Ampai masih dominan untuk melestarikan nilai-nilai adat sakai yang telah berakulturasi dengan Islam. Sehingga wajar para tokoh sakai berupaya mengusulkan Desa Kesumbo Ampai sebagai Desa Adat. Karena dari prasarat yang ditetapkan dalam UU Desa Adat sudah terpenuhi.

Ketiga desa tempat bermukimnya suku sakai tersebut yakni Desa Kesumbo Ampai; Bumbung dan Desa Petani, saat 
ini berada dalam wilayah kecamatan Bathin Solapan. Pemukiman Sakai di desa Petani terletak di dusun Blading tempat bermukim mayoritas warga sakai tetapi tidak lagi memiliki hutan adat dan tidak pula disebut sebagai desa adat, sehingga adat dan trdisi warga sakai sudah mulai kurang dilestarikan karena mereka harus berbaur dengan etnik lain seperti Jawa, Batak, Minang dan Melayu. Oleh karena itu tantangan bagi warga sakai untuk hidup atau terpaksa berada dalam satu lingkup pemukiman yang heterogen berbaur dengan penduduk lain. Proses pembauran di desa Petani dengan beberapa bentuk seperti suku Sakai sudah mau menikah dengan suku lain, misalnya adalah ketua RW I dusun Blading desa Petani Bapak Musriadi. Ia adalah keturunan warga sakai menikahi perempuan Jawa dan telah dikaruniai 3 orang anak. Bapak Kepala Dusun Blading desa Petani Bapak Jamal berasal dari blasteran Bapak Melayu dan ibu asli Sakai. (Wawancara : Jamal, 06-09-2017) Di Keecamatan Mandau terdapat juga suku Sakai yang mengelompok di desa Pematang Pudu sekitar $\pm 70 \mathrm{KK}$.

Mata pencarian suku Sakai di desa Kesumbo Ampai; desa Bumbung; desa Petani; dan desa Pematang Pudu umumnya adalah petani sawit. Rata-rata mereka memiliki 2 Hektar kebun sawit tetapi kurang menghasilkan buah, karena tidakng pemelihaaraan dan pupuk. Kalaupun ada yang menghasilkan panen yang memuaskan, itu hanya sebagian kecil suku sakai saja yang sering berkonsultasi dan berinteraksi dengan masyarakat di luar suku sakai. Di desa Kesumbo Ampai, kebun yang digarap oleh oleh masyarakat sakai adalah tanah adat, dan hanya memiliki sertifikat tanah tunggal, bukan milik perseorangan. Apabila suku sakai ingin memiliki lahan milik sendiri dengan bersertifikat perorangan, maka mereka harus membeli lahan yang ada di luar tanah adat. Sedangkan sebagian suku sakai ada yang menjadi nelayan dalam mencukupi kebutuhan sehari-hari mereka. Sebagian suku sakai di desa Petani mata pencarian mereka pencari ikan. Mereka memancing ikan air tawar di Jembatan I dan Jembatan II di sungai Pudu desa Petani. (Observasi: 08-08-2017).

Penduduk Sakai sebelum tahun 1970 lebih senang tinggal di hulu sungai dan membangun rumah dan ladang mereka di tepi sungai atau rawa. Pada waktu itu sarana penghubung mereka adalah jalur air. Namun saat ini jalur penghubung dalam kehidupan mereka adalah jalur darat dengan menggunakan sepeda, motor, bahkan sebagian suku sakai memakai mobil sebagai transportasi untuk angkutan barang dan orang. Awal mula Suku sakai juga terpencar dalam satuan wilayah yang dinamakan perbatinan. Saat ini perbatinan ada empat, pertama Batin Sobanga; kedua Bathin Solapan, ketiga Batbin Bomban dan keempat batin batuah. Bathin Sobanga pimpinan Bapak M. Yatim wilayahnya meliputi beberapa desa di Kecamatan Bathin Solapan seperti Desa Kesumbo 
Ampai, Desa Bumbung. Batin Batuah terdapat desa Pematang Pudu Kecamatan Mandau. Bathin Solapan wilayahnya meliputi penduduk Sakai yang menghuni Kecamatan Pinggir seperti di Desa Penaso dan Muara Basung (Wawancara, Swardino, 05-092017). Selanjutnya keempat Bathin Bomban pimpinannya Bapak Bukhari, berada di desa Petani dusun Blading. Kewenangan Bathin banyak berkurang seiring dengan munculnya pemerintah Desa seperti Lurah atau Kepala Desa. Sejak tahun 2000 perbatinan tidak adalagi kekuasaannya di institusi formal, namun secara adat dan simbolisasi pelestarian nilai-nilai adat istiadat dalam ritual sistem perbathinan masih dibutuhkan oleh warga Sakai.

Sebenarnya telah diberlakukan UU Desa Nomor 6 tahun 2014 terkait tentang prasarat suatu desa ingin menjadi Desa Adat terdapat dalam Pasal 96 hingga Pasal 111 menguraikan dengan rinci tentang Penataan Desa Adat; Kewenangan Desa Adat; Pemerintahan Desa Adat dan; Peraturan Desa Adat. Karena kewenangan Desa adat sangat kuat dalam pelestarian nilai-nilai sosial dan adat istiadat asli Suku Sakai, maka salah satunya Ketua bathin Solapan M. Yatim berharap pemeliharaan dan penataan yang baik tentang hutan adat yang luasnya kurang lebih $260 \mathrm{Ha}$. Hutan adat di Desa Kesumbu Ampai, Kecamatan Bathin Solapan, Kabupaten Bengkalis, ini berada di dusun Dusun Sebanga Asal.
Pada masa lalu kedudukan Bathin dalam masyarakat Sakai adalah sangat penting dalam mengatur tatanan sosial masyarakat. Kedudukan batin diperoleh seseorang karena diwarisi oleh ayahnya yang batin. Orang yang mewarisi batin biasanya anak laki-laki tertua, pandai dan cerdik, inilah seringkali syarat terakhir yang lebih penting bagi penentuan seseorang untuk menduduki jabatan bathin. Di samping itu sarat lain seorang bathin harus pandai berkata, berwibawa dan menguasai ilmu ghaib (Husni Thamrin, 2003: 124-126). Anak yang akan dipilih menjadi batin biasanya diajari orang tuanya sedikit demi sedikit berbagai pengetahuan magis orang sakai dan seluk beluknya. Pengangkatan seorang Batin pada zaman kerajaan Siak selalu dilakukan dengan suatu upacara Penobatan yang diikuti dengan pesta minum-minum selama tujuh hari tujuh malam. Tugas seorang Batin dalam zaman kerajaan Siak yang kemudian juga dilanjutkan dalam masa kolonilaisme Belanda.(Parsudi Suparlan, 1995: 82).

Otoritas kekuasan Perbathinan mulai berkurang saat berlaku UndangUndang pemerintahan Desa No. 5 tahun 1979. Kebijakan pemerintah ini berhasil menggeser pemimpin non-formal yang awalnya sangat beragam di suatu daerah atau desa di seluruh tanah Air. Kepemimpinan Bathin misalnya yang menjadi tradisi dalam masyarakat Sakai; Gampong di Aceh, Nagari di Sumatera Barat, Marga di Palembang, dan Banjar di Bali. Kemudian beberapa tahun 
berikutnya keluar pula Undang-Undang Pemerintahan Desa UU No. 32 Tahun 2004 tentang Pemerintah daerah. Pada tahun 2014 dikeluarkan lagi penyempurnaan pemerintahan desa, dalam UU Desa (UU No. 6 Tahun 2014), materi tentang pemerintahan desa terutama diatur pada pasal 23-66. .

Pada awalnya suku Sakai sering di sebut dengan suku terasing sebagai mana suku-suku terpencil lain seperti di wilayah suku anak dalam di Jambi, suku Ekagi di Papua, Suku Loitas di Nusa Tenggara Timur; suku Samin di Jawa Tengah, suku Badui di Banten, suku Tengger di pinggiran Gunung Bromo Jawa Timur, suku Gayo di Aceh, suku Dayak Sekadau di Kalimantan Barat. Menurut Suparlan, penamaan masyarakat suku terasing kurang tepat(Abd. Ghofur, 2014: 92), sebaiknya mereka disebut orang Asli sebagaimana dilakukan di Malaysia, karena mereka adalah penduduk yang paling "asli" di bumi nusantara ini. Kelompok masyarakat Suku Sakai, untuk istilah sekarang termasuk dalam Komunitas Adat Terpencil (KAT) sebagai pengganti istilah masyarakat terasing. Selanjutnya istilah tersebut dikukuhkan dengan Surat Keputusan Presiden No 111 tahun 1999.

Menurut Husni Thamrin, bahwa orang Sakai di Desa Kuala Penaso masuk dari desa Muara Basung saat ini masuk wilayah Kecamatan Pinggir Bengkalis diduga keras berasal dari Semenanjung
Malaya (Malaysia). Ini dikuatkan dengan temuan yang dilakukan oleh Hans Kalipke, seorang antropolog Jerman yang melakukan penelitian di Riau tahun 1968-1998; berdasarkan analisa antropologi fisik dan budaya struktur sosial dan budaya Sakai, ada kesamaan dengan orang Semang di Semenanjung Malaya (Husni Thamrin, 2003: 124-126. Kelompok suku Sakai hingga saat ini masih berada dalam kondisi yang sangat memprihatinkan dari aspek ekonomi, sosial, dan budaya.

Nama sakai dalam sebutan bagi penduduk pengembara yang terpencil dari lalu lintas kehidupan dunia kekinian di Riau. Sebagian mereka juga tinggal di Kecamatan Kandis kabupaten Siak bagian hulu sungai Siak. Di wilayah ini penduduk sakai berada dalam perlindungan Bathin Betuah, sedangkan di Kecamatan Mandau dan Bathin Solapan berada dalam wilayah kekuasaan Bathin Sobanga dan batbin Bomban (Wawancara : Swardino, 08-09-2017). Menurut Boehari Hasmi dalam Parsudi Suparlan, menjelaskan bahwa orang sakai datang dari kerajaan Pagaruyung Minangkabau Sumatera Barat. Penduduk sakai bermigrasi dalam dua tahap, pertama diperkirakan terjadi sekitar abad ke $14 \mathrm{M}$ langsung ke daerah Mandau dan sekitarnya seperti persebaran tersebut di atas.(Parsudi Suparlan, 1995: 82).. Sedangkan penduduk sakai gelombang kedua diperkirakan tiba di Riau abad ke $18 \mathrm{M}$, yang datang menuju kerajaan Gasib selang beberapa waktu kerajaan 
itu hancur diserang oleh kerajaan Aceh Darussalam, sehingga penduduknya lari ke dalam hutan belantara, mereka membangun rumah dan ladangnya secara terpisah.

\section{Sosial-Keagamaan}

Orang Sakai di beberapa Desa Di Kecamatan Mandau dan Kecamatan Bathin Solapan seperti di desa Kesumbo Ampai, Desa Bumbung, Desa Petani, dan Desa Pematang Pudu umumnya beragama Islam. Karena dipengaruhi oleh ekspansi Islam zaman kerajaan Siak Sri Indrapura (1723-1942). Namun dalam pengamalan ajaran Islam masih ada kecenderungannya bercampur dengan paham keagamaan lama yang bersifat sinkretis. Pada saat dilakukan acara-acara ritual adat-istiadat seperti memasuki hutan, mendirikan rumah; acara kelahiran; kematian dan lainnya masih bercampur dengan hal-hal mistik. Barangkali hal ini disebabkan karena tidak ada kontinuitas dakwah Islam yang dikembangkan oleh kerajaan Siak, maupun lembaga lain setelah Indonesia merdeka. Suku Sakai di wilayah ini adalah menganut agama Islam yang bertarekat karena sejak dari awal Islam masuk dengan praktek tarekat yang dibawa oleh pemimpin tarekat. Inti dari agama nenek moyang masyarakat Sakai adalah kepercayaan terhadap keberadaan 'bantu', atau mahluk gaib yang ada di sekitar mereka di pohon-pohon, tempattempat keramat dan benda-benda keramat lainnya baik dalam kategori animisme maupun dinamisme.

Islam berkembang dalam masyarakat Sakai cenderung dipengaruhi oleh Tharikat Naqsabadiyah Babussalam(UU Hamidi, 1992: 86). yang dibawa oleh Syekh Abdul Wahab Rokan (1811-1826 M) Syekh Abdul Wahab dilahirkan tanggal 19 Rabiul Akhir 1230 $\mathrm{H}$ di Kampung Danau Runda, Desa Rantau Binuang Sakti Kecamatan Kepenuhan Kabupaten rokan hulu. Saat zaman kerajaan Siak Sri Indrapura tahun 1916 M, Sultan memberikan ruang bagi para khalifah pemimpin tariqat untuk mengislamkan orang sakai di kawasan ini. Dengan menggunakan pendekatan Islam tarekat masyarakat mulai meninggalkan kepercayaan pra-islamnya. Syekh Ali Ibrahim adalah khalifah yang ditugaskan untuk mengembangkan Islam di daerah Rokan, hingga memasuki kawasan masyarakat Sakai Bathin Solapan. Dalam pelaksasnaan Syekh Ali dibantu oleh Khalifah Panjang dan Khalifah Mahmud, sedangkan didaerah tersebut juga dibantu oleh Lebai Dowi dan Imam abdul khalid.(Ahmad Fuad, 2001: 16).

Suku sakai dan sebagian penduduk non-sakai di desa Petani masih rutin menyelenggarakan kegiatan suluk, karena di desa ini berdiri selain surau Suluk juga berdiri madarasah Suluk sejak tahun 1983 yang bernama Madrasah Suluk Tarekat Naqsabandiyah Syeikh Sulaiman. Madrasah Suluk ini dipimpin oleh 
Khalifah Ahmad Jamban. Beliau adalah adalah anak dari syeikh $\mathrm{H}$ Sulaiman khalifah pendiri awal Madrasah Suluk dan Surau tarekat Naqsabandiyah di Desa Petani Kecamatan Bathin Solapan (Wawancara; Khalifah Ahmad, 05-092017). Di Madrasah Suluk tersebut rutin dilakukan praktek suluk tarekat Naqsabandiyah secara reguler baik lakilaki maupun perempuan secara bersamaan di ruang terpisah dalam Surau yang sama. Pengikut tarekat ini umumnya berasal dari kalangan generasi usia 40 tahun ke atas. Pelaksanaan suluk bervariasi ada 10 hari dan ada pula 40 hari secara berturut-turut. Surau tarekat di desa Kesumbo Ampai tidak rutin dalam menyelenggarakan praktek suluk sebagaimana di Madrasah Suluk tarekat Naqsabandiyah desa Petani. Meskipun ceramah keagamaan dan dakwah Islam disampaikan oleh para khalifah yang berasal dari tarekat naqsabadiyah. Di desa Kesumbo areal tanah adat dan hutan adat berdiri 2 rumah ibadah pertama masjid dan kedua adalah surau tarekat naqsabandiyah rumah suluk (Observasi: 05-09-2017).

\section{Perubahan Sosial-budaya}

Ada beberapa faktor yang menjadi penyebab terjadinya kelambanan dalam perubahan sosial budaya masyarakat suku Sakai. Pertama, kehidupan sosial suku Sakai mayoritas penduduknya punya karakteristik berkelompok dalam komunitas yang homogen yaitu satu rumpun etnik. Misalnya di desa
Kesumbo Ampai meneglompok di Dusun Sebanga Asal; Suku Sakai di desa Bumbung mengelompok di Dusun Talang Jenang; dan Suku Sakai di desa Petani mengelompok di Dusun Blading.

Pemukiman penduduk yang homogen tersebut, hanya terdiri dari mayoritas Suku Sakai, sulit untuk cepat menerima cara hidup dan budaya dari masyarakat luar. Hal ini dilatarbelakangi oleh kuatnya adat dan tradisi yang memagari kehidupan penduduk Sakai. Pola pemukiman penduduk seperti ini tentu saja akan menghambat arus pengalaman, pengetahuan dari luar masuk ke dalam komunitas Sakai. Pemukiman Sakai yang mengelompok dalam satu wilayah seperti di Desa Kesumbo Ampai, lebih spesifik lagi berada di dusun Sebanga Asal. Dusun Sebanga Asal tempat pemukiman Sakai, di mana dibangun beberapa bangunan Rumah adat sebagai simbol tradisi dan adat istiadat yang membentengi masyarakat Sakai sekaligus tempat untuk melakukan acara adat seperti penyambutan bulan suci ramadhan, pengangkatan atau penabalan ninik mamak dan Bathin; serta penyambutan tokoh-tokoh penting baik dari pemerintah maupun tokoh adat dari luar. Homogenitas kelompok sakai di dusun sebanga Asal didukung pula dengan adanya hutan adat $260 \mathrm{Ha}$; pemukiman penduduknya menempati tanah desa adat; adanya sistem sosial perbathinan dan hukum ada yang masih kuat. 
Kedua, faktor kemiskinan dan lemahnya akses penduduk di bidang pendidikan, ekonomi, dan sosial. Mayoritas penduduk sakai mendapatkan penghidupan dari bertani, sehingga sebagian besar belum mampu menjadi petani yang bisa menyekolahkan anakanak mereka ke jenjang yang lebih tinggi. Tanah yang dikelola oleh penduduk Sakai di dusun Sebanga Asal Kesumbo Ampai adalah tanah adat bukan milik pribadi. Ketiga, faktor adat istiadat dan tradisi yang begitu kuat menyebabkan penduduk sakai dalam merespon perubahan sosial dari luar lebih ketat untuk membentengi diri agar tidak terpengaruh dan bahkan cenderung menutup diri dengan dikelilingi hutan adat dan tanah adat serta hukum adat. Penduduk sakai berpegang teguh pada adat dan nilai tradisi yang begitu kuat karena mereka menganggap warisan budaya nenek moyang adalah sesuatu yang agung dan luhur serta mesti dilestarikan.

Selanjutnya ada beberapa faktor yang menjadi penyebab terjadinya perubahan sosial budaya yang dinamis dalam masyarakat suku Sakai. Diantaranya Pertama, faktor latar belakang pendidikan; adanya perkawinan campur antara orang sakai dengan etnik lain baik perkawinan pria sakai dengan perempuan bukan sakai maupun sebaliknya; kedua, adanya pelatiban dan pembinaan bagi sebagian orang sakai dari berbagai pihak; dan keteladanan dari pemimpin lokal baik pemimpin formal maupun informal; serta interaksi yang intens dan mobilitas yang tinggi sebagian penduduk Sakai. (Wawancara : Swardino, 08-09-2017).

Ada beberapa fakta di lapangan terkait beberapa faktor cepatnya perubahan sosial budaya bagi sebagian kecil penduduk Sakai. Pertama, faktor pendidikan dan kawin campur (blasteran), Swardino adalah contoh salah seorang tokoh sakai yang telah mengenyam pendidikan tinggi. Tingkat Sarjana (S1) jurusan Administrasi Negara di UIR. Ia juga telah menyelesaikan (S2) di jurusan yang sama di UNRI. Latar belakang keluarga Swardino lahir dari ibu orang sakai dan ayah berasal dari etnik Jawa (Jawa Tengah). Dua faktor tersebut yang menjadikan proses percepatan perubahan sosial-budaya dan kerangka berpikir Swardino dalam beberapa aspek lebih maju dibanding penduduk Sakai lainnya. Contoh lain adalah Dr, Muhammad Agar seorang Sakai yang juga telah lebih dulu berpikiran maju karena telah menyelesaikan pendidikan tinggi ke jenjang program Doktor. yaitu Dr. Muhammad Agar, kini bermukim di Hamburg Jerman karena telah diambil sebagai anak angkat oleh Prof. Hans Kalipke sejak beliau umur 5 tahun (Wawancara : Rasyid, 06-09-2017).

Faktor pendidikan masyarakat sakai bisa berubah dapat dicontohkan munculnya tokoh Syahril pemuda Sakai yang bisa menjadi anggota DPRD Bengkalis; Bupati Bengkalis bapak Amril 
Mukminin; dan dari generasi mudanya saat ini Andika Putra Kenedi yang mau merubah dirinya dengan mengambil jurusan teknik Geologi dan lainnnya. Bahkan saat ini pemerintah kabupaten Bengkalis mendirikan sekolah Menengah Kejuruan ( SMKN 2) di Desa Kesumbo Ampai, agar banyak dari siswa-siswa suku Sakai sekolah.

Terjadinya percepatan perubahan sosial-budaya bagi sebagian orang sakai juga bisa dilihat dari aspek adanya pembinaan dan pelatiban dalam berbagai bidang. Sebagai contoh bidang peternakan dan pertanian. Salah seorang sakai bernama bapak Ahmad Jais, telah mendapatkan pelatihan cara beternak Sapi di Ciamis Jawa Barat. Kini ia mencoba beternak sapi secara lebih baik telah memiliki 39 ekor Sapi.

\section{Desa Adat dan Hutan Adat}

Desa Adat menurut Undangundang Desa Nomor 6 Tahun 2014 adalah pengakuan masyarakat hukum adat sebagai subjek hukum dalam sistem pemerintahan, yaitu menetapkan unit sosial masyarakat hukum adat seperti nagari, huta, kampong, mukim dan lainlain sebagai badan hukum publik. Selanjutnya Pasal 103 UU Nomor 6 tahun 2014, Desa adat sebagai badan hukum publik mempunyai kewenangan tertentu berdasarkan hak asal usul, yaitu : Pengaturan dan pelaksanaan pemerintahan berdasarkan susunan asli. Pengaturan ulayat atau wilayah adat; Pelestarian nilai sosial- budaya adat;
Penyelesaian sengketa adat berdasarkan hukum adat; Pemeliharaan ketertiban masyarakat desa adat berdasarkan hukum adat; dan Pengembagan kehidupan hukum adat.

Pemukiman penduduk sakai di kecamatan Bathin Solapan khususnya di Desa Kesumbo Ampai pada dasarnya sudah layak menjadi Desa Adat, karena sudah memenuhi sarat yang ditetapkan Undang-Undang Desa Nomor 6 Tahun 2014 sebagaimana persyaratan utamanya adalah adanya Hutan Adat; Rumah Adat; struktur organisasi Bathin atau struktur kelembagaan asli; pelestarian nilai-nilai sosial dan adat istiadat.oleh karena itu pihak Desa Adat Kesumbo Ampai telah mengajukan kepada pihak pemerintah kabupaten Bengkalis untuk dibuat surat ketetapan.(Wawancara : Andika Putra Kenedi, 06-09-2017). Desa Adat selain menjalankan tugas kewenangan berdasarkan hak asal usul diatas dibawah kewenangan Bathin yang diketuai oleh Bapak M. Yatim. Sedangankan kewenangan desa adat yang dilimpahkan pemerintah pusat dan daerah dijalankan oleh Kepala desa dalam hal ini dipimpin oleh Ibu Anita sebagai Kepala Desa Kesumbo Ampai. Banyak contoh Desa Adat yang berkembang di Indonesia dan telah ditetapkan oleh pemerintah untuk kelestarian Adat serta untuk proses percepatan pembangunan seperti Desa Wae Rebo Di Nusa Tenggara Timur (NTT; Desa Les Di Bali; Desa Sindangbarang di Jawabarat; Kampung 
Naga di Jawa Barat dan desa Silanan di Sulawesi Selatan.

Hutan adat maupun tanah adat tidak bisa diperjualbelikan kepada pihak manapun dan surat tanahnya hanya tunggal. Penduduk sakai bisa menguasai dan mendapatkan kepemilikan tanah, tetapi harus mencari tanah yang berada di luar tanah adat dan butan adat. Hutan Adat di Desa Kesumbu Ampai ini kaya dengan sumber daya hayati karena di dalamnya banyak terdapat kayu kulim, seminai, kempas, gaharu, meranti, kepayang dan lain-lainnya. Disamping itu di hutan adat Desa kesumbu Ampai ini juga masih banyak tumbuhan berkhasiat untuk obat-obatan, sehingga sampai saat ini masyarakat Sakai bila ada yang sakit masih banyak yang mengandalkan ramuan obat tradisional dengan cara meracik obat-obatan tradisional dari tumbahan di hutan adat tersebut. Bapak Yatim sebagai Ketua Bathin Solapan desa Kesumbu Ampai sangat berharap agar hutan adat tersebut dijadikan sebagai objek wisata hutan. Karena sekiranya hutan adat ini dijadikan objek wisata, tentu akan ramai pengunjung yang datang ke sini dan secara otomatis akan meningkatkan potensi perekonomian masyarakat Sakai di Desa ini (Wawancara: M. Yatim, 07-09-2017).

\section{Program pemberdayaan Suku Sakai}

\section{Pemberian beasiswa}

Program pemberian beasiswa kepada suku Sakai dilakukan oleh beberapa pihak diantaranya pemerintah Kabupaten Bengkalis; pemerintah propinsi; dan pihak swasta seperti PT Chevron Pacific Indonesia (Chevron); pertamina maupun lainnya kepada putra-putri sakai dari jenjang sekolah Dasar (SD) hingga ke Perguruan Tinggi. Berdasarkan penuturan dari Humas HPMSR (Himpunan Pemuda dan Mahasiswa Sakai Riau), Andika Putra Kenedi bahwa salah satu Pihak swasta Chevron (CPI) mulai tahun 2000 selalu menyediakan beasiswa kepada putra-putri Sakai yang melanjutkan pendidikan pada jenjang SI. Pada tahun 2017 ini PT Cevron memberi beasiswa Program SI kepada mahasiswa Sakai yang melanjutkan ke Perguruan Tinggi seperti UNRI; UIR; UIN ; Universitas Tabrani dan Universitas Lancang Kuning. Tahun ini tercatat sebanyak 76 mahasiswa Sakai yang tinggal di Asrama Sakai Riau di Jalan Taman Karya Tampan Pekanbaru semuanya mendapatkan beasiswa dari Chevron dengan rincian Biaya masing-masing orang sebesar Rp. $\quad 1500.000$ untuk kebutuhan bulanan; ditambah Rp. 250.000/bulan biaya buku dan untuk biaya SPP persemester tergantung jumlah besar masing-masing Perguruan Tinggi/Fakultas/Prodi yang diambil (Wawancara : Andika Putra Kenedi, 06-09-2017). 


\section{Bidang Peternakan}

Pada tahun 2015, PT Chevron Pacific Indonesia (Chevron) memberikan bantuan sebanyak 360.000 bibit ikan air tawar kepada masyarakat di sekitar wilayah operasi propinsi Riau. Bantuan berupa bibit ikan Lele, Nila, Patin dan Gurame tersebut diserahkan kepada perwakilan kelompok tani/ternak di Kabupaten Bengkalis, Rokan Hilir, dan Rokan Hulu. Berkaitan bantuan bibit ikan air tawar di wilayah kabupaten Bengkalis diberikan kepada penduduk Sakai yang tinggal di desa Pematang Pudu kecamatan Mandau. Bantuan ini merupakan bagian dari program Corporate Social Responsibility (CSR) Perusahaan melalui Promoting Sustainable Integrated Farming, Small Enterprise Cluster and Microfinance Access (PRISMA Chevron) yang sudah dikembanagkan sejak tahun 2015 (Wawancara: Sazli, 08-08-2017).

Pada tahun 2016 pihak CPI (Chevron Pacific Indonesia) melalui community Development juga memberikan 250 ekor ayam kampung untuk kelompok tani di Desa Buluh Manis dan 300 ekor bebek untuk kelompok tani di Desa Petani, Kecamatan Mandau (sejak 2017 Desa Petani masuk Kecamatan Bathin Solapan). Bantuan ayam dan bebek ini untuk dapat melatih keterampilan dalam beternak dan meningkatkan kesejahteraan masyarakat Sakai.
Kelompok peternak ayam dan bebek di desa Petani tidak hanya berasal dari masyarakat suku sakai saja sebagaimana di Desa Kesumbo Ampai, tetapi kelompok tani desa Petani gabungan dari beberapa suku yang diberi nama dengan Sakai Rokan Jawa (Saroja).

$$
\text { Pemberdayaan masyarakat }
$$
bidang peternakan juga dilakukan Prisma Chevron kepada salah satu kelompok tani yang dipimpin oleh masyarakat Sakai bernama bapak Ahmad Jais pada tahun 2012 (Wawancara : Abmad Jais, 08-08-2017). Beliau memimpin Kelompok TaniTernak Sakai Mandiri Sejahtera (KTT SMS). Bapak Ahmad Jais beserta kelompoknya telah mendapatkan pelatihan cara beternak Sapi beberapa tahap. Pada tahap pertama kali pelatihan diikuti di Ciamis Jawa Barat di mana bapak Ahmad jais sebagai salah satu pesertanya. Ahmad Jais merupakan salah seorang dari 20 orang yang telah dikirim ke Ciamis Jawa Barat untuk mengikuti pelatihan beternak sapi oleh CPI (Chevron) pada tahun 2012, kemudian pelatihan dilanjutkan tahap kedua untuk kelompok tani lain sebanyak 20 orang lagi tahun 2013 di Pekanbaru. Ahmad Jais adalah penduduk sakai yang berani terjun sebagai peternak sapi setelah mengikuti pelatihan selama dua minggu. Saat observasi di lapangan, beliau telah memiliki 39 ekor Sapi. Sapi sebanyak 9 ekor 
adalah bantuan yang dilakukan CPI awalnya sebanyak 2 ekor pada tahun 2013. Pada tahun 2016 bapak Ahamad Jais membeli 30 ekor sapi bakalan khusus penggemukan saja. Ia berusaha mencari pinjaman dari Bank Syariah Mandau atas Jaminan dari pihak CPI melalui PRISMA.

Pemberdayaan bidang peternakan juga dilakukan Chevron ke desa Petani pada tahun 2014 dengan cara memberikan bantuan 31 ekor sapi. Bantuan sapi ini tidak hanya diberikan kepada suku sakai tetapi juga masyarakat lain Jawa dan Batak dan Melayu karena di desa Petani penduduk sakai hanya terdiri dari 112 KK. Mereka sudah tinggal dalam kelompok masyarakat yang heterogen. Bantuan Sapi ternak diberikan kepada 3 kelompok tani. Masing-masing kelompok tani terdiri dari 10 orang. Dan masing-masing orang diberikan bantuan 1 ekor sapi betina. Dari 30 ekor sapi yang diserahkan ke desa petani dengan perbandingan 30 ekor sapi dan 1 ekor sapi jantan. Secara rinci bisa dikalkulasi menjadi 3 Kelompok Tani, dengan masing-masing kelompok 10 orang dan masing-masing orang mendapatkan 1 ekor sapi betina. (Wawancara : Jamal, 06-092017).

Pada tahun 2017 saat penulis melakukan survei dan wawancara, ternyata bantuan sapi yang dipelihara untuk dikembangbiakkan oleh suku sakai tidak ada lagi yang tersisa, karena menurut bapak Kepala Dusun Blading desa Petani Bapak Jamal dan RW 3 Bapak Musriadi (Dusun Blading mayoritas dihuni penduduk Sakai) ada beberapa sebab kegagalan ini, diantaranya sapi mati mendadak; kemudian ada alasan sapinya sakit lalu disembelih dan sebagian lain sapinya dijual karena kurang bisa merawat sehingga sapinya kurus dan tidak hamil-hamil. (Wawancara : Jamal, 0609-2017).

Selain CPI (Chevron), terdapat juga pemberdayaan yang dilakukan oleh perusahaan Ivomas pada tahun 2012. Perusahaan Ivomas telah membantu masyarakat suku Sakai seperti bantuan buku, baju, tas dan uang saku bagi siswa, dan pihak Ivomas juga memberikan jaminan kesehatan bagi masyarakat suku Sakai dalam bentuk mendatangkan dokter.

\section{Pertanian dan perkebunan}

Salah satu pemberdayaan yang dilakukan PT Arara Abadi kepada suku Sakai Kesumbo Ampai adalah dalam bentuk penanaman kebun karet seluas $300 \mathrm{Ha}$ di lahan tanah adat. PT Arara Abadi adalah perusahaan yang bergerak dalam pengelolaan HTI (Hutan Tanaman Industri) jenis akasia. Letak HTI milik PT Arara Abadi ini berdampingan langsung dengan tanah adat sakai yang seluas 300 Ha. Perusahaan Arara Abadi 
setelah melakukan negoisasi dengan tokoh Sakai sebagai bentuk Community Development, bersedia menanami lahan kosong tersebut dengan pohon karet secara bertahap. Saat ini sudah 200 $\mathrm{Ha}$ yang sudah ditanami oleh perusahaan dan sebagian besar telah berproduksi. (Wawancara : Andika Putra Kenedi, 06-09-2017). Sayangnya berdasarkan musyawarah adat, pengerjaan menakik getah (karet) diupahkan kepada orang jawa yang tinggal di sekitar Desa kesumbo Ampai tetapi tidak bermukim dalam desa adat Sakai. Saat ini harga karet turun, sehingga bagi hasil yang didapat oleh suku sakai dari produksi kebun karet tersebut kurang memadai.

Kebun karet seluas $300 \mathrm{Ha}$ yang berasal dari tanah adat tersebut bukan berasal dari hutan adat yang dilindungi. Hutan adat suku sakai seluas $260 \mathrm{Ha}$ berada di antara pemukiman penduduk sakai dusun Sebanga asal. Hutan adat maupun tanah adat tidak bisa diperjualbelikan kepada pihak manapun dan surat tanahnya hanya tunggal. Hutan Adat di Desa Kesumbu Ampai banyak terdapat kayu kulim, seminai, kempas, gaharu, meranti, kepayang dan tumbuhan berkhasiat untuk obatobatan. Suku Sakai bila ada yang sakit masih mengandalkan obat-obatan tradisional dari tumbahan di hutan adat dengan cara diracik.
Pemberdayaan bagi petani Sakai bidang pertanian dilakukan oleh Chevron dimulai dengan pembentukan kelompok pertanian Terpadu Suku Sakai di Kelurahan Pematang Pudu. Bapak Mus Mulyadi diangkat sebagai ketua kelompok tani menjelaskan bahwa kelompok tani dilibakan dalam pelatihan tentang tata cara bercocok tanam sayur-sayuran seperti cabe, kangkung dan kacang panjang. Cevron juga melatih petani sakai lain untuk beternak bebek dan burung puyuh serta pelatihan budidaya ikan air tawar seperti ikan lele dan dan ikan patin. Setelah diberikan pembinaan dan pelatihan, para petani diberikan bantuan sesuai dengan kebutuhan, antara lain pupuk; bibit; pakan untuk ternak. dan pendampingan dalam proses kelangsungan sebelum panen. Hasilnya memang positif.

\section{Pengalokasian dari Dana Desa}

Prioritas penggunaan Dana Desa untuk program dan kegiatan bidang Pemberdayaan Masyarakat Desa, dialokasikan untuk mendanai kegiatan yang bertujuan meningkatkan kapasitas warga dalam pengembangan peningkatan pendapatan dan kesejahteraan mereka. Anggaran Dana Desa selain untuk pembiayaan infrastruktur di desa juga disalurkan Kepala desa Ibu Anita pada program pemberdayaan masyarakat seperti memberikan bantuan rutin kepada 
anak-anak miskin dan anak yatim dalam bentuk uang; bantuan untuk operasional kegiatan masjid dan mushalla masing-masing sebesar 10 Juta; Posyandu 10 Juta; PKK 10 Juta; Poskamling 10 Juta dan untuk kegiatan lain yang sifatnya insidentil. ADD juga dilakukan untuk pembelian ambulan desa.(Wawancara : Amrizal, 09-09-2017).

\section{Program dari Dana UED-SP}

(Usaha Ekonomi-Desa Simpan Pinjam)

Program ini digagas dan dilaksanakan oleh mantan Gubernur Riau HM Rusli zainal saat ia menjabat. Kelanjutannya pemerintah Kabupaten Bengkalis masa Bapak Herliyan Saleh tahun 2011. Program UED-SP sudah diimplementasikan sejak 7 tahun lalu untuk seluruh desadesa dalam membantu peningkatan perekonomian masyarakat di desa yang bersifat pinjaman lunak khususnya bagi usaha kecil. Namun Program UED-SP yang semula tahun pertama berasal dari APBD propinsi, selanjutnya untuk empat tahun terakhir sudah menjadi program pemerintah kabupaten Bengkalis pada kepemimpinan Bapak Bupati Herliyah Saleh serta dilanjutkan pula oleh Bapak Bupati Amril Mukminin saat ini.

Pemberdayaan Suku Sakai dari jenis UED-SP dengan cara penyaluran kredit lunak dan pengembalian dana yang berkelanjutan, masyarakat menjadi mandiri dalam menggali potensi usaha ekonomi di desa. Perputaran uang UED-SP sat ini antara 5 Miliar- 11 Miliar. Bila di desa Induk sejak awal dikelola maka perputaran uang mencapai lebih 10 Miliar, namun bila di desa pemekaran hanya kisaran 5 Miliar. UED-SP di desa Kesumbo Ampai menurut Bapak Tuigiman perputaran uangnya hingga 2017 mencapai 11 Miliar.(Wawancara : Togiman, 05-09-2017). Uang tersebut dipinjamkan kepada setiap masyarakat yang membutuhkan. Namun harus melengkapi syaratsyarat diantaranya memakai anggunan. Setiap peminjam harus menyerahkan borg (jaminan). Pinjaman dengan menggunakan jaminan maksimum Rp. 20-30 juta sedangkan Pinjaman dengan tidak menggunakan jaminan maksimum Rp. 10 juta.

Berdasarkan penjelasan bapak Toegiman terkait masyarakat sakai di desa Kesumbo Ampai ini dalam keaktifan memanfaatkan dana UEDSP dan cicilan bulanan ia prihatin karena pertama, sebagian besar masyarakat Sakai tidak bisa meminjam lebih besar dari angka maksimum karena sebagian masyarakat sakai yang tinggal di desa adat, tidak memiliki sertifikat tanah untuk dijadikan jaminan. Kedua, Suku Sakai umumnya memanfaatkan dana 
pinjaman UED-SP untuk pemeliharaan kebun sawit dan karet seperti untuk membeli pupuk; membeli racun rumput; biaya penebasan semak dan penyemprotan rumput. Namun banyak suku sakai meminjam untuk alasan pemeliharaan tanaman, tetapi kenyataanya dana pinjaman untuk kebutuhan harian yang sifatnya konsumtif bukan untuk pembiayaan produktif (Wawancara : Togiman, 05-09-2017).

Ketiga, banyak suku Sakai di Kesumbo Ampai ini yang menunggak atau tidak bisa mencicil pinjaman UED-SP akibat dari kebun yang kurang produktif dan dana yang dipinjam hanya untuk kebutuhan konsumtif. Menurut bapak Ketua UED-SP pertengahan tahun 2017 tunggakan pinjaman khusus dari masyarakat Sakai Kesumbo Ampai mencapai 200 Juta rupiah. Bahkan ada peminjam sengaja tidak mencicil sejak pertama ia meminjam. Karena ada anggapan sebagian kecil suku sakai bahwa dana tersebut merupakan hibah atau bantuan bukan pinjaman.

Bila masyarakat pengguna pinjaman lunak UED-SP tidak dapat mengembalikan cicilan perbulan selama tiga bulan akan ada pembinaan dan teguran, hingga masuki bulan keenam maka akan ada penyitaan terhadap aset yang dijaminkan. Tetapi karena banyak masyarakat suku Sakai di Kesumbo Ampai dalam meminjam tidak menggunakan jaminan sehingga hingga kini tunggakan semakin membesar. Langkah-langkah yang diusulkan bapak Toeigiman kepada ibu Anita kepala Desa yaitu bagi peminjam yang menunggak atau tidak mencicil hutangnya akan ditunda proses pengurusan administrasi di Desa seperti membuat KTP; Akta kelahiran; KK; surat Tanah; suratsurat keterangan untuk anak sekolah dan lainya. .(Wawancara : Togiman, 05-09-2017).

Kegagalan dan ketidakmampuan sebagian warga sakai dalam mengelola pinjaman UED-SP menurut Swardino perlu berbagai pihak untuk melakukan bimbingan, pelatihan dan pembinaan kepada suku sakai. Sebab dalam beberapa kasus ada sebagian kelompok masyarakat sakai yang telah dilatih secara baik seperti bapak Ahmad Jais ternyata bisa menjadi peternak Sapi yang sukses. (Wawancara : Swardino, 07-08-2017). Sejak tahun 2016 dana UED-SP menjadi bagian yang dikelola oleh BUMDes (Badan Usaha Milik Desa), di Desa Kesumbo Ampai BUMDes menaungi tiga unit usaha secara terpisah menajemenya yaitu pertama UED-SP; kedua kantin yang lokasinya di samping kantor Desa dan ketiga, pengelolaan Air Bersih.

\section{Kesimpulan}

Dari uraian di atas dapat diambil beberapa kesimpulan sebagai berikut : 
Pertama, Persebaran pemukiman Suku Sakai di Kecamatan Bathin Solapan yaitu di Desa Kesumbo Ampai; Desa Petani (dusun Belading $\pm 112 \mathrm{KK}$ ) dan Desa Bumbung (dusun V Talang Jenang atau Talang Nagoi $\pm 60 \mathrm{KK})$. Mayoritas orang sakai bermukim di Desa Kesumbo Ampai $\pm 173 \mathrm{KK}$ yang terdiri dari tiga Dusun yaitu dusun Sebangar Asal; Dusun Patang Butam; dan dusun Tanah Pujung. Suku Sakai mayoritas menempati wilayah Dusun Sebanga Asal di mana di dusun ini pula berdiri rumah adat; di kelilingi hutan adat seluas $\pm 260 \mathrm{Ha}$.

Kedua, program pemberdayaan bagi suku sakai meliputi beberapa hal yaitu pemberian beasiswa; bidang peternakan; pertanian dan perkebunan; program Alokasi Danan Desa dan program UED-SP. Bila dikelompokkan program itu ada dikategorikan sifatnya produktif dan non produktif.

Ketiga, pemberdayaan bagi suku sakai yang sifatnya non-produktif tidak banyak mengalami kendala seperti bantuan langsung dalam bentuk beasiswa; bantuan rumah RLH; Ambulan; bantuan uang untuk karang taruna; posyandu; PKK; surau dan masjid.

Keempat, problem program program pemberdayaan yang produktif seperti bantuan sapi bakalan; bibit ayam kampung; itik; bebek; ikan lele; gurami dan nila; kemudian bantuan benih sayur kangkung; bayam; kacang panjang dan lainnya. Ada pula program pinjaman lunak UED-SP banyak suku sakai tidak bisa memanfaaatkan dan gagal dalam menjalankan program tersebut, karena kurangnya pendampingan; bimbingan dan pelatihan yang berkelanjutan dari mulai proses pelaksanaan sampai pada hasil (out put). Namun ada sebagian kecil penduduk sakai yang berhasil mengikuti program pemberdayaan tersebut. 


\section{DAFTAR KEPUSTAKAAN}

Chaidar, 2002, Dasar-Dasar Merancang dan Melakukan Penelitian Kualitatif, (Jakarta : Alwasilah Pustaka Jaya)

Edi Suharto, 2010, Membangun Masyarakat Memberdayakan Masyarakat, (Bandung; Refika Aditama)

Friedman, F., 1998, Empowerment: The Politic of Alternative Development. (Cambridge: Blackwell,)

Garna, Judistira, K. 1999, Masyarakat Baduy dan Siliwangi, (Depsos RI Gramedia. Jakarta)

Hamidi, UU, 1996, Islam dan masyarakat Melayu di Riau, (Pekanbaru, UIR Pres)

Husni Thamrin, 2003, Sakai, Kekuasaan, Pembangunan dan Marginalisasi, (Pekanbaru : gagasan Press,)

Kartasasmita, Ginandjar. 1996. Pembagunan Untuk Rakyat.Jakarta; Cides)

Kontjoroningrat, 1992, Metode Penelitian Masyarakat, (Jakarta : Gramedia)

Liliweri, Alo, 2002, Gatra-Gatra Komunikasi Antar Budaya (Yoyakarta, Pustaka Pelajar).

Mathew Miles \& Hubermen Micahel, 1992, Analisis data Kualitatif, terjemahan (Jakarta : UI Press)

Moelong Lexy, 2000, Metode penelitian Kualitatif, (Bandung : Remaja Rosda Karya)
Mohamad Zen, 2006, Orang Laut: Studi Etnopedagogi, (Jakarta: Yayasan Bahari Nusantara)

Mulyana, Dedi, 2002, Metode Penelitian Kualitatif, (Bandung : Remaja Rosda Karya,)

Rinnusu, Singkronisasi Perencanaan dan Penganggaran Pembangunan Daerah, (makalah Pelatihan Anggaran Responsif Gender, 2014).

Sri Sumantri, HRT, 2008, Otonomi Daerah, (LP3; Jakarta).

Soetomo, 2008, Pembangunan Masyarakat, Merangkai sebuah Kerangka, (Bentang, Yoyakarta)

Suparlan, Parsudi, 1998, Orang Sakai di Riau-Masyarakat Terasing dalam Masyarakat Indonesia. (Jakarta: Yayasan Obor Indonesia).

Taliziduhu Ndraha, 2006, Pembangunan Masyarakat. (Rineka Cipta: Jakarta) 